\title{
What Influence Do Migrants' Characteristics have on Volume of Remittances in Nigeria?
}

\author{
Akin-Olagunju, O.A. \\ Fabusuyi, E.O. \\ Adesina, M.A. \\ Yusuf, S.A. \\ Department of Agricultural Economics \\ University of Ibadan \\ Nigeria.
}

\begin{abstract}
Migrants' remittances have been viewed as a tool of economic growth and development. Many studies in Nigeria have focused on the effect of remittances on welfare of migrants' households. Hence, this paper evaluates the influence of migrants' characteristics on volume of remittances using nationally representative migration data. Results showed that residence in rural area prior to migration reduces remittance by $32.7 \%$ in comparison to living in urban location owing to reduced opportunities. Also, the amount of money repatriated was positively related to the age and educational attainments of migrants while wage earners and the unemployed formed bulk of the migrants. Two-way solution is proposed from the results of this study: repatriation of funds from overseas should be made easy through appropriate financial policies while self-employment sector in the country of origin should be developed by consolidating government support for small and medium scale enterprises (SMSEs).
\end{abstract}

Keywords: international migration; remittances; skilled migrants; economic development

\section{Introduction}

Migrant refers to an individual, group or community that moved from one location to another, usually in search of 'economic betterment' (Zimmermann, 2016). The imbalance in the demographics between the North and the South coupled with the high population of extremely poor people in developing countries which was estimated at 724 million, has been a good recipe for North-bound movement (Christiaensen et al., 2019). Although, it is likely that poor people are more 'incentivized' to migrate, there is tendency for the rich to want to settle abroad, too (Bodgan, 2018; Seitz, 2019). In Nigeria, for example, there is currently a mixed/complex situation wherein those that are considered economically advantaged leave well-paid jobs in the country and migrate to take up jobs of lower status abroad. However, this is still sequel to the general economic situation in the country as Seitz (2019) has submitted that low wage and poor market conditions fuel labour migration.

Migration studies have for many years focused on the negative effects that the movement of high-skilled labour from developing countries pose to revenue generation and loss of human capital, termed 'brain drain' whose effects evidences even suggest are minimal (Kone \& Ozden, 2017). However, recent studies have beamed searchlight on the positive gains of such movements which include remittances for the source country, knowledge gain and economic integration. Rapoport (2016) mentioned the global integration assistance that skilled migrants confer on their countries. Furthermore, research has shown that migration usually have positive effects on the wages in the source country as a result of labour supply wage with the effect varying from sector to sector (Bouton et al., 2011). Cantore \& Cali (2015) noted that migration, whether temporary or permanent, is beneficial to the source country in terms of increased income and poverty reduction through remittances, trade, foreign direct investment and human capital accumulation. These ultimately cushion the effect of 'brain drain'.

Contributions of migrants to the home economy range from cash and kind remittances, sending money for economic development projects, investing in stocks and bonds in the source country, foreign direct investment and taking part in political discourses (Zimmermann, 2016). In the same vein, Seitz (2019) opined that leaving 'hostile' environment back home brings positive welfare outcomes for the households left behind. In such instances, remittances are usually determined by the economic downturn back home and ultimately help in relieving poverty. 
Remittances still represent significant source of fiscal resources in many developing countries. However, heavy reliance on this external funding source might not be totally healthy for any economy because economic downturn in the destination country might impact negatively on the other. For instance, World Bank (2019) observed that the sluggish economic growth in Russia has implications for the economy of countries such as Kyrgyz Republic, Moldova, Tajikistan, and Ukraine because they are highly dependent on remittance. Apart from remittances, skilled emigration has somewhat resulted in the human capital development of developing countries rather than the negative reports of loss of human capital that is preponderant in migration literature (Clemens, 2016). Despite the gains for both ends, however, opposition to immigration into developed countries is strong because the immediate 'concentrated' cost masks the long-term 'diffused' benefits (World Bank, 2019).

The field of migration research has evolved in terms of increased number of literature and diversity of topics being treated, moving beyond issues of rural-urban migration and remittances to the more development-oriented discourses (Clemens et al., 2014). In Nigeria, apart from the traditional rural-urban migration area, studies have focused on the effects of migration/remittance on poverty, inequality and household welfare (Olowa \& Awoyemi, 2012; Olowa \& Shittu, 2012; Olowa et al., 2013), relationship between remittances and economic growth (Ojapinwa, 2012; Afaha, 2013; Loto \& Alao, 2016) and more recently, migrants' remittances and financial inclusion (Ajefu \& Ogebe, 2019; Anetor, 2019) together with migration, labour mobility \& household poverty (Rufai et al. 2019). This paper, however, focuses on the effects that characteristics of migrants, at source and destination, could have on the amount being repatriated. This is pertinent in identifying characteristics that might have fueled migration and how these and the current situation in the destination country affect economic well-being of migrants. To this end the paper seeks to answer the following questions: what influence do migrants' characteristics have on volume of remittances in Nigeria?

\section{Materials and Methods}

\subsection{Data and sampling}

Secondary data obtained from migration surveys conducted by the Development Prospect Group of the World Bank in 2009 in some selected African countries including Nigeria, were used for this study. Data were collected on socioeconomic and migration characteristics of migrants of Nigerian origin and their households. These include remittances being sent in cash and kind, education level of migrants, gender, age, marital status, residence before migration, relationship to the household head, number of transfers made in the last one year, channel of transfers and current work situation of the migrants, among others.

The sampling frame used for the survey was the 2006 National Population Census. The National Bureau of Statistics (NBS) provided a randomly selected set of enumeration areas and households spread across all states in the Federation from the 2006 sampling frame. Stratified random sampling technique was used to select areas according to population and the expected prevalence of migrants. The NBS sample enumeration areas were distributed such that within each state, local government areas from each senatorial zone were included in the sample, with Local Governments in each state nearly evenly distributed between rural and urban areas. In all, a total of 3188 enumeration areas were selected. These enumeration areas were unevenly spread across states: some states in the North West (Kano, Katsina, and Jigawa), and a few in the South South (Akwa Ibom and Delta) had over 100 enumeration areas selected while others such as Imo and Abia in the South East, and Borno, Gombe and Taraba in the North East, had as few as 20 enumeration areas selected. This selection partially reflects the relative population distribution and number of Local Government Areas in the component states. Data from 645 international migrants' households from the total enumeration areas were used for analysis.

\subsection{Analytical Technique}

This study adopted Ordinary Least Square (OLS) method. Ordinary Least Square (OLS) is a type of linear least square method for estimating unknown parameters in a linear regression model. It helps to identify the relationship between the dependent variable $\mathrm{Y}_{\mathrm{i}}$ and independent (explanatory) variables $\mathrm{X}_{\mathrm{i}}$. The goal of Ordinary Least Square is to closely 'fit'/model the linear relationship between the independent and dependent variables by minimizing the sum of the squares in the difference between the observed and predicted values of the dependent variable. The relationship between the dependent variable and explanatory variable can be described using the equation of the line of best fit with $\alpha$ indicating the value of $\mathrm{Y}$ when $\mathrm{X}$ is equal to zero (also known as the intercept). This study employed the multiple linear regression because it examined the relationship between the dependent variable $\mathrm{Yi}$ and more than one independent variable $\mathrm{X}_{\mathrm{i}}$. The multiple linear regression model is based on the assumptions that: (a) there is a linear relationship between the dependent variable and the independent variables, (b) the independent variables are not too 
highly correlated with each other, (c) $\mathrm{Y}_{\mathrm{i}}$ observations are selected independently and randomly from the population, (d) residuals should be normally distributed.

Using the equation of the line of best fit, the multiple regression equation is given as follows:

$\ln Y_{i}=\alpha+\beta_{1} X_{1}+\beta_{2} X_{2}+\ldots+\beta_{n} X_{n}+e_{i} \ldots(1)$

Where: $Y_{i}=$ total remittances which comprises remittances in cash and kind.

$\mathrm{e}_{\mathrm{i}}=$ error term

$\beta=$ change in $Y$ that is associated with a unit change in $X$.

The independent variables $\mathrm{X}_{\mathrm{i}}$ in this model are described as follows:

$\mathrm{X}_{1}=$ Age (years)

$\mathrm{X}_{2}=$ Sex $($ female $=1$, male $=0)$

$\mathrm{X}_{3}=$ Relationship to household head

$\mathrm{X}_{4}=$ Length of stay (years)

$\mathrm{X}_{5}=$ Marital status

$\mathrm{X}_{6}=$ Current work situation

$\mathrm{X}_{7}=$ Frequency of transfer

$\mathrm{X}_{8}=$ Educational attainment before migration

$\mathrm{X}_{9}=$ Residence before migration (urban $=1$; rural $=0$ )

\section{Results and Discussion}

\subsection{Socio-economic characteristics of respondents}

Table 1 shows the summary of migrants' socio-economic characteristics. The result showed the mean age of the respondents to be 34.3 years. Also, $40.31 \%$ of the migrants are within the age range of $16-30$ years, $48.06 \%$ are within the age bracket $31-45$ years, $11.32 \%$ are within the age range of $46-60$ years while $0.31 \%$ were of the range $61-77$ years. Most migrants $(88.37 \%)$ are thus in their productive years (16-45 years). The result of gender summary indicates that $74.73 \%$ of migrants were males. More migrants being males could be as a result of socio-cultural constraints which prevent many women from migrating. Also, $63.88 \%$ of the migrants were married while $28.84 \%$ and $6.36 \%$ were single and engaged, respectively. However, the data did not indicate whether respondents were married before or after migration.

Furthermore, results showed that $60.0 \%, 34.42 \%$ and $4.19 \%$ of the respondents attained tertiary, secondary and primary education levels, respectively before migrating. Majority of the respondents are highly skilled and this is the factor that brings about the brain drain syndrome. A little above half of the respondents (52.05\%) lived in urban areas while $47.95 \%$ lived in rural areas. These percentages are close indicating that people in urban areas are likely to migrate as much as those in rural areas. However, migration incidence among the urban populace is a bit higher. Luthra et al. (2016) discovered a new generation of Polish migrants who are younger, more educated and living in urban areas prior to migration, though less gender differentiated. The table also shows the distribution of work situation of migrants before leaving. Approximately one-third (31.47\%) of the respondents were engaged in paid employment while $14.57 \%$ were self-employed. However, $30.39 \%$ of migrants were unemployed which could have served as a motivation for them to migrate. Full-time students made up $22.79 \%$ of the respondents and few of the respondents $(0.31 \%)$ were retirees.

\subsection{Distribution of respondents by migration characteristics}

Results in Table 2 show that approximately one-third of the migrants left Nigeria in search of work or job opportunity, $18.14 \%$ left for educational purposes while $13.02 \%$ left because of marital arrangement. Only $4.21 \%$ of respondents left in order to join other family members abroad. The results imply that the main driver of migration is a better (mostly, economic) opportunity, as noted by Zimmermann (2016). The distribution of respondents by money-sending channel reveals that the most important channel is Western Union (35.04\%). Also, almost a quarter of the remittance transfers were sent directly to banks for onward collection, $13.18 \%$ of respondents sent remittance via friends and relatives while only $9.92 \%$ brought remittances themselves during visits. The frequency of money transfer also shows that most migrants $(30.85 \%)$ transferred twice, about $28.06 \%$ sent remittance just once in a year, while $14.88 \%$ transferred money thrice. Thus, majority of the respondents are more likely to remit $1-3$ times in a year. Volume distribution reveals that large percentage of the respondents (77.83\%) sent less than $\$ 250,000$; one out of every ten migrants sent between $\$ 251,000$ and $\$ 500,000$; while $4.50 \%$ sent above $\$ 1,000,000$ in one year. 


\subsection{Determinants of volume of migrants' remittances}

The regression results are given in Table 3. Ten (10) main variables were considered in the model. These include age of migrant, square of age, gender, highest school before leaving, duration of stay, marital status, frequency of transfer, relationship to household head, residence before migration and current work situation of migrant. All coefficients were derived with respect to the natural logarithm of total remittance.

Post-estimation diagnostic tests were carried out for the regression analysis. Ramsey Regression Specification Error (RESET) Test using powers of the fitted values of $\ln \left(\mathrm{Y}_{\mathrm{i}}\right)$ was done to test for omission of variables. The nonsignificance of the $F$-value $(F=1.36$; Prob $>F=0.2550)$ led to the acceptance of the null hypothesis of no omitted variables. Robust form of the OLS model was also carried out to control for heteroskedasticity. Furthermore, link-test was done to ensure that modules operate correctly in combination while the Variance Inflation Factor (VIF) test for multicollinearity was also conducted on the sample. Eighteen (18) out of the twenty-five (25) variables for which VIF values were generated had VIF values less than 10.00 (the maximum value which indicate presence of multicollinearity). Overall, the mean VIF value of 8.42 indicates absence of multicollinearity.

In the OLS regression, fifteen (15) variables were statistically significant at different levels. Ten (10) of the significant variables: residence before migration (rural), sex (female), square of age, relationship with household head (partner, son/daughter-in-law, grandson/granddaughter), marital status (separated) and current work situation (self-employed, retired, housewife); were negatively related to the amount of remittance while five (5) variables: age, length of stay, marital status (widowed), education attainment before migration (tertiary) and number of transfers showed positive relationship.

The results showed that residing in the rural area before migrating abroad reduces remittance by $32.7 \%$ in comparison living in urban location. This might be as a result of more pressing need to take care of the initial low standard of living usually prevalent in rural locations. The results also revealed that a year increase in age increases remittance by $18.4 \%$ while remittance reduces by $0.2 \%$ with a unit increase in square of age. The results point to the fact that the older the migrant, the higher the amount of money repatriated. However, as the migrant ages, the amount sent home reduces probably as a result of loss of vigour or retirement. Estimated coefficient with respect to the female gender is -0.222 and is significant at $\mathrm{P}_{\alpha 0.05}$. Being a female reduces remittance by $22.2 \%$ compared to being a male. The estimated coefficient with respect to tertiary educational attainment is $0.550\left(\mathrm{P}_{\alpha 0.01}\right)$, meaning that attaining tertiary educational attainment increases remittance by $55.0 \%$ in relation to non-formal education. The positive outcome is as a result of skills that have been acquired which are usually in high demand in destination countries.

The estimated coefficient with respect to frequency of money transfer is 0.081 and is significant at $\mathrm{P}_{\alpha 0.01}$. The total remittance will increase by $8.1 \%$ as a result of a unit increase in frequency of money transfer. Among the marital status categories, estimated coefficients for the separated and the widowed were the only statistically significant, with values of -1.263 (at $\mathrm{P}_{\alpha 0.01}$ ) and 1.540 (at $\mathrm{P}_{\alpha 0.01}$ ), respectively. All other factors remaining constant, separation of respondents and being widowed will decrease total remittance by $126.3 \%$ and by $154.0 \%$, respectively. Relationship of migrant with household head comprises six sub-categories but only coefficients for partners $\left(\mathrm{P}_{\alpha 0.01}\right)$, son/daughter-in-law $\left(\mathrm{P}_{\alpha 0.05}\right)$ and grandson/granddaughter $\left(\mathrm{P}_{\alpha 0.05}\right)$ to household heads were statistically significant. Total remittance decreases by $165.0 \%, 98.5 \%$ and $87.9 \%$ for the different categories, respectively. This might be that the migrants are more likely to send remittance to farther relatives. Total remittance will reduce by $38.4 \%$ if migrant is self-employed, it drops by $54.0 \%$ if the migrant is retired from work while it decreases by $91.0 \%$ when respondent is a housewife. All other subcategories are non-significant.

\section{Conclusion}

Migration and remittances have strong, significant impact on the socio-economic development of the households and society in general. People migrate mainly for economic reasons making migration, and hence remittance, a livelihood adaptation strategy. This study provides evidence on the core determinants of volume of migrants' remittances. Even though migrants' remittances may be a small share of the nation's GDP, it probably amounts to a large share of the income of recipient households and may therefore have substantial impact on the ability of these households to cater for their needs. Remittance is greatly influenced by migrants' socio-economic characteristics. Therefore, a remittancereceiving country like Nigeria needs to provide a friendly economic environment that can improve the flow of remittance. This could be through sound macro-economic policies, including stable exchange rates, basic physical infrastructure, improved market integration, reliable financial and other institutions, transparent legal system and good governance. Conditions that can prime the economy for development and equip it adequately to benefit from this external stimulus are highly needed. 
On one hand, people migrate mainly because of economic opportunities, thus necessitating creation of additional formal jobs or support for the self-employed in order to prevent brain drain and the attendant national economic loss. Giambra \& McKenzie (2019) noted that the self-employed are less likely to migrate. On the other hand, inflow of remittances as a positive outcome of migration should be encouraged by taking steps to improve the financial sector. Efficient and competitive financial sector will reduce the cost associated with remittances flow. Government should adopt strict policy measures to regulate international remittance inflows to Nigeria by ensuring proper investment of greater percentage of these funds. This can be done by insisting that all remittances above certain level be accompanied with an investment plan or risk a stipulated government action.

\section{References}

Afaha, J.S. (2013). Migration, remittance and development in origin countries: Evidence from Nigeria. African Population Studies, 27(1): 53-69.

Ajefu, J.B. \& Ogebe, J.O. (2019). Migrant remittances and financial inclusion among households in Nigeria. Oxford Development Studies, 47(3): 319-335.

Anetor, F. O. (2019). Remittance and economic growth nexus in Nigeria: Does financial sector development play a critical role? International Journal of Management, Economics and Social Sciences (IJMESS), 8(2): 116-135.

Bodgan, L. (2018). Who wants to leave? Migration motivations in Moldova. Journal of Identity and Migration Studies, 12(1): 83-95.

Bouton, L., Paul, S. \& Tiongson, E.R. (2011). The impact of emigration on source country wages: Evidence from the Republic of Moldova. Policy Research Working Paper 5764, The World Bank, Washington, DC.

Cantore, N. \& Cali, M. (2015). The impact of temporary migration on source countries. International Migration Review, 49(3):697-726.

Christiaensen, L., Gonzalez, A. \& Robalino, D. (2019). Migration and jobs: Issues for the $21^{\text {st }}$ century. Policy Research Working Paper 8867, The World Bank, Washington DC.

Clemens, M.A., Ozden, C. \& Rapoport, H. (2014). Migration and development research is moving far beyond remittances. World Development, 64:121-124.

Clemens, M.A. (2016). Losing our minds? New research directions on skilled emigration and development. International Journal of Manpower, 37(7):1227 - 1248.

Giambra, S. \& McKenzie, D. (2019). Self-employment and migration. Policy Research Working Paper 9007, The World Bank, Washington DC.

Kone, Z.L. \& Ozden, C. (2017). Brain drain, gain and circulation. KNOMAD Working Paper 19, Global Knowledge Partnership on Migration and Development.23pp.

Loto, M.A. \& Alao, A.A. (2016). Remittances and the growth of the Nigerian economy. EJBE 6(2):210-232.

Luthra, R., Platt, L. \& Salamonska, J. (2016). Types of migration: The motivations, composition and early integration patterns of 'new migrants' in Europe. International Migration Review, 1-36. https://doi.org/10.1111/imre.12293.

Ojapinwa, T. (2012). Determinants of Migrants' Remittances in Nigeria: An Econometrics Analysis. International Journal of Humanities and Social Science, 2(14): 295-301.

Olowa, O.W. \& Awoyemi, T.T. (2012). Determinants of migration and remittances in rural Nigeria. Journal of Development and Agricultural Economics, 4(7): 191-198.

Olowa, O.W. \& Shittu, A.M. (2012). Remittances and income inequality in rural Nigeria. Business Management and Economics, 3(5): 210-221.

Olowa, O.W., Awoyemi, T.T., Shittu, A.M. \& Olowa, O.A. (2013). Effects of remittances on poverty among rural households in Nigeria. European Journal of Sustainable Development, 2(4): 263-284.

Rapoport, H. (2016). Migration and globalization: What's in it for developing countries? International Journal of Manpower, 37(7):1209 - 1226.

Rufai, M., Ogunniyi, A., Salman, K.K., Oyeyemi, M. \& Salawu, M. (2019). Migration, labour mobility and household poverty in Nigeria: A gender Analysis. Economies, 7(101):1-24.

Seitz, W. (2019). International migration and household well-being: Evidence from Uzbekistan. Policy Research Working Paper 8910, The World Bank, Washington DC.

World Bank (2019). Migration and brain drain in Europe and Central Asia. ECA Economic Update Fall 2019. The World Bank, Washington DC.

Zimmermann, A.C.K. (2016). Diaspora economics: New perspectives. International Journal of Manpower, 37(7):1110-1135. http://dx.doi.org/10.1108/IJM-07-2016-0151. 


\section{Appendix}

Table 1: Socio-economic characteristics of respondents

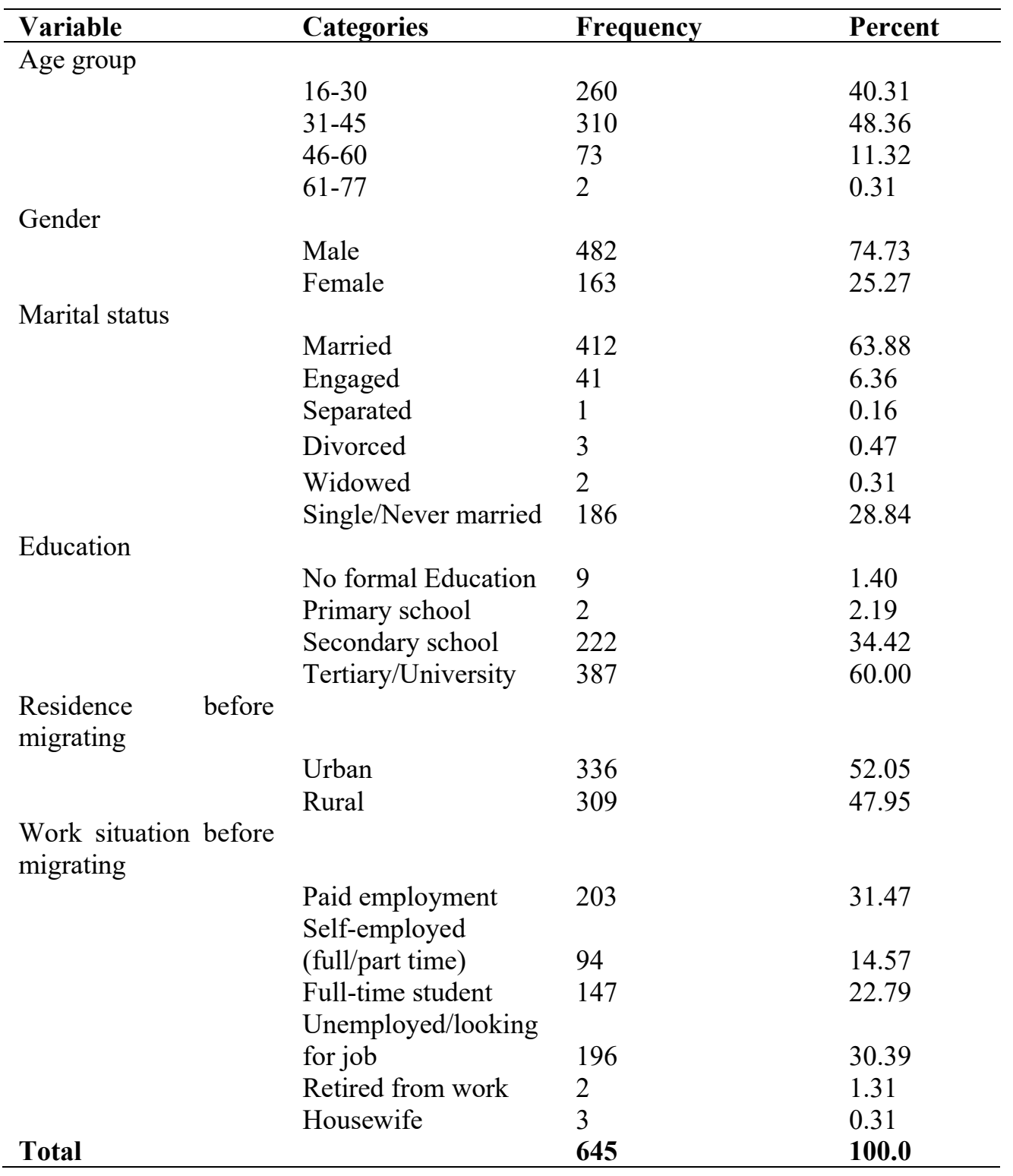


Table 2: Migration characteristics of respondents

\begin{tabular}{|c|c|c|c|}
\hline Variable & Categories & Frequency & Percentage \\
\hline \multicolumn{4}{|c|}{ Reason for migrating } \\
\hline & Education & 117 & 18.14 \\
\hline & Search for work & 208 & 32.25 \\
\hline & Job transfer/Job opportunity & 209 & 32.4 \\
\hline & Marriage arrangement & 84 & 13.02 \\
\hline & To join other family members & 27 & 4.21 \\
\hline \multicolumn{4}{|c|}{ Money-sending channel } \\
\hline & Western Union & 226 & 35.04 \\
\hline & MoneyGram & 27 & 4.19 \\
\hline & Money postal order & 1 & 0.16 \\
\hline & Direct transfer to bank account & 152 & 23.57 \\
\hline & Bank as paying agent for money transfer & 64 & 9.92 \\
\hline & Foreign Exchange Bureau & 1 & 0.16 \\
\hline & Informal individual agent & 22 & 3.41 \\
\hline & Through friend or relative & 85 & 13.18 \\
\hline & Brought back himself during visit & 64 & 9.92 \\
\hline & Pre-paid cards/ATM card, reloadable cards & 2 & 0.31 \\
\hline & Internet money transfer & 1 & 0.16 \\
\hline \multicolumn{4}{|c|}{ Frequency of money transfer } \\
\hline & Once & 181 & 28.06 \\
\hline & Twice & 199 & 30.85 \\
\hline & Thrice & 96 & 14.88 \\
\hline & Four times & 53 & 8.44 \\
\hline & Five times & 34 & 5.27 \\
\hline & Six times & 30 & 4.65 \\
\hline & Seven times & 3 & 0.47 \\
\hline & Eight times & 7 & 1.09 \\
\hline & More than eight times & 42 & 6.53 \\
\hline \multicolumn{4}{|c|}{ Distribution of remittance by volume ( } \\
\hline & $\leq 250,000$ & 502 & 77.83 \\
\hline & $251,000-500,000$ & 71 & 11.01 \\
\hline & $501,000-750,000$ & 18 & 2.79 \\
\hline & $751,000-1,000,000$ & 25 & 3.88 \\
\hline & $>1,000,000$ & 29 & 4.50 \\
\hline & Total & 645 & 100.0 \\
\hline
\end{tabular}


Table 3: Parameter Estimates of the Determinants of Volume of Migrants' Remittances in Nigeria

\begin{tabular}{|c|c|c|c|}
\hline $\begin{array}{l}\text { Dependent variable: } \\
\text { Log of remittance }\end{array}$ & Coefficient & Robust s.e. & t-statistics \\
\hline \multicolumn{4}{|l|}{ Residence before migration } \\
\hline Rural & $-0.327^{* * *}$ & 0.103 & -3.18 \\
\hline \multicolumn{4}{|l|}{ Sex } \\
\hline Female & $-0.222^{* *}$ & 0.106 & -2.08 \\
\hline Age & $0.184^{* * *}$ & 0.0329 & 5.59 \\
\hline Age-squared & $-0.002^{* * *}$ & $4.24 \mathrm{e}-04$ & -5.22 \\
\hline \multicolumn{4}{|l|}{ Relationship with household head } \\
\hline Spouse & -0.041 & 0.615 & -0.07 \\
\hline Partner & $-1.65^{* * *}$ & 0.503 & -3.28 \\
\hline Son/Daughter & -0.615 & 0.422 & -1.46 \\
\hline Son/Daughter-in-law & $-0.985^{* *}$ & 0.489 & -2.02 \\
\hline Brother/Sister & -0.566 & 0.429 & -1.32 \\
\hline Grandson/granddaughter & $-0.879^{* *}$ & 0.439 & -2.00 \\
\hline Length of stay & $0.021^{*}$ & 0.0125 & 1.70 \\
\hline \multicolumn{4}{|l|}{ Marital status } \\
\hline Engaged to be married & 0.148 & 0.213 & 0.70 \\
\hline Separated & $-1.263^{* * *}$ & 0.268 & -4.71 \\
\hline Divorced & -0.295 & 1.110 & -0.27 \\
\hline Widowed & $1.540^{* * *}$ & 0.538 & 2.86 \\
\hline Single/Never Married & 0.004 & 0.118 & 0.03 \\
\hline \multicolumn{4}{|c|}{ Educational attainment before migration } \\
\hline Primary School & -0.272 & 0.307 & -0.89 \\
\hline Secondary School & 0.310 & 0.198 & 1.56 \\
\hline Tertiary/University & $0.550^{* * *}$ & 0.195 & 2.82 \\
\hline \multicolumn{4}{|l|}{ Current work situation } \\
\hline Self employed & $-0.384^{* * *}$ & 0.137 & -2.81 \\
\hline Full-time student & -0.314 & 0.335 & -0.94 \\
\hline Unemployed/looking for work & -0.1429 & 0.228 & -0.63 \\
\hline Retired from work & $-0.540^{* *}$ & 0.260 & -2.07 \\
\hline Housewife & $-0.910^{* * *}$ & 0.353 & -2.58 \\
\hline Number of transfers & $0.081^{* * *}$ & 0.021 & 3.95 \\
\hline
\end{tabular}

No. of Observations $=645$

R-squared $=0.2127$

Mean VIF: 8.42

RESET Test: $\mathrm{F}(3,616)=1.36$; Prob. $>\mathrm{F}=0.2550 \quad$ Level of significance: ${ }^{* * *} 1 \%,{ }^{* *} 5 \%$ and ${ }^{*} 10 \%$. 